\title{
Factors Affecting the Household Saving Participations on 'Equb': A Study on the Three Major Towns of Wolaita Zone, Southern Ethiopia
}

\author{
Lidetu Alemu Anjulo (Assistant Professor) \\ Lecturer, Department of Management: Wolita Sodo University. P.o.box:138 \\ Ewun Markos Madda \\ Agriculture and Development officer, Wolaita Sodo Zuriya Woreda
}

\begin{abstract}
Equb is a form of traditional cooperative or traditional self-help group in Ethiopia. Equb is a financial form of traditional cooperative formed voluntarily. It is a rotating saving and credit type association whose members make regular contributions to a revolving loan fund. This research study is aimed at examining factors affecting household participation on Equb, conducted on three major towns of Wolaita Zone i.e. Sodo, Boditi and Areka towns. The sample size is determined by using Taro Yemane's simplified formula from the total household of 61499 , sample size of 283. A causal cross sectional survey was conducted among all the household participants. The primary data was collected through structured questionnaire and selected by using systematic random sampling among households dwelling in Areka, Boditi and Sodo town. The data was analyzed by using STATA and both descriptive and inferential statistics were used. The multiple linear regression model was employed with household participation in Equb as the dependent variable. Th findings of the study shown that factors such as income, economic, social and psychological is significantly affecting the saving habit of urban households. In this case it is recommended that financial institutions, government and other stakeholders should support and work on awareness creation for those sectors.
\end{abstract}

Keywords: Equb, Household, Participants, Savings, traditional cooperatives

DOI: $10.7176 / \mathrm{JPID} / 48-01$

\section{Introduction}

\subsection{Background of the Study}

Business exploitation, expansion and modernization depend on capital investment, given good management. Most business people in developing nations are poor and so require credit. Providing credit to poor borrowers has remained a challenge; as credit markets in these regions are faced with the problem of enforcement and imperfect information among others (Seibel, 2001). Government intervention in the form of ownership of banks, regulation and subsidization of credit has equally failed to allocate credit to poor borrowers (Udry, 1994). Institutional problems such as the lending conditions which limit access of investors to credit facilities have not been adequately addressed (Vargese, 2005).

Informal financial institutions such as Rotating Savings and Credit Associations (ROSCAs) and their participants have received growing attention over the last two decades. A recent study on urban Ethiopia provided detailed evidence of the important role of informal finance in consumption smoothing of households (Alvi and Dendir, 2009). A particular emphasis on studying ROSCAs has been placed on their role in resource mobilization. Informal finance, once the preserve of anthropologists and sociologists, is capturing the attention of economists.

In Ethiopia, a country where it is not uncommon to find cooperative activities among the people (Engdawork, 1995), informal self-help institutions have existed for long in their own version. The Ethiopian version of RoSCA is called equb. The small equbs could be started within a group based on strong ties like friendship, business associates, school mates, or within the neighborhood. In large equbs, individuals that do not have close relationship might become members though each member needs to be known by at least some other members in the group, and their moral standing should be known by the community (Mauri, 1987).

\subsection{Statement of the Problem}

"Equb" offers a savings mechanism for households in Ethiopia and it is a high contributing factor for economic sustainability of households. However, now a day due to some challenges "equb" may not play such activities. In practice we observe individuals/household join "equb" for multiple reasons without a focus exclusively on one motive as indicated earlier, and the participants of "equb" are decreasing. The reason might be the rising cost of living. The study investigates what attention should be given for "equb" to achieve the sustainable life of households.

'Equbs' are traditional instruments for financing households for social or investment purposes and are very 
common among Ethiopian community. However, since there areno returns (except the amount invested) from 'equbs', it remains a puzzle why people engage in an 'equb' where there are no additional benefits. Perhaps individuals could have enjoyed some interest by putting the periodical payment in a saving account in a bank instead of in an 'equb'. Nevertheless, recent and modernized 'equbs' are currently introducing a new variety of 'equb' that introduced some interest on 'equbs'.

In spite of the different justifications they give to the raison d'être of RoSCAs, researchers in economics (Besleyet al., 1993, 1994; Dejene, 1993), development studies (Bouman, 1994,1995; Tirfe, 1999) or anthropology (Ardener, 1964) agree on the huge role and potential that RoSCAs have in the daily life of the society practicing them. Study cited by Bouman (1995) reveal a RoSCA membership rate of 50\% to $95 \%$ among adult population in Nigeria, Cameroon, Gambia, Liberia, Republic of Congo, Togo and Ivory Coast. It is estimated that an amount equivalent to half of the national saving in Cameroon, double amount of saving in organized sector in Kerala (India), and $8 \%$ to $10 \%$ of the GDP in Ethiopia is mobilized by RoSCAs. In a recent study in Ethiopia, Temesgen (2008) has found that the annual turnover of four equbs he considered in Addis Ababa, the capital city, was equivalent to $0.15 \%$ of the net current deposit maintained by all commercial banks in the country by the end of August, 2007.

Moreover, though there are many researches on formal finance like banks, insurance companies and micro finance institutions, the informal sector has been neglected among academicians and regulatory bodies. Bringing to light these informal 'capital markets' might suggest policy adjustment for both regulators and other stakeholders.

In addition, this study will ensure a proper understanding of effecting factors of household participation on "equb" which engaged on three major towns of Wolaita zone.

\subsection{Research Questions}

- What is the relationship between income factors of households and "equb" participants in the three major towns of wolaita zone?

- What is the relationship between expenditure factors of households and "equb" participants?

- What is the relationship between social factors of households and "equb" participants?

- What is the relationship between economic factors of households and "equb" participants?

- What is the relationship between psychological factors of households and "equb" participants?

\subsection{Research Hypothesis}

H1 : There is a significant relationship between Income factors and participation on Equb.

H2 : There is a significant relationship between Expenditure factors and participation on Equb.

H3 : There is a significant relationship between Psychological factors and participation on Equb.

H4 : There is a significant relationship between Economic factors and participation on Equb.

H5 : There is a significant relationship between Social factors and participation on Equb.

\subsection{Objectives of the Study}

\subsubsection{General Objective}

Factors affecting the household saving participations on 'equb': a study on the three major towns of wolaita zone, southern ethiopia

\subsubsection{Specific Objectives}

1. To identify the factors which affect the participation of households on "equb".

2. To analyze the relationship of identified factors with the participation of households on "equb".

3. To assess the effect of demographic factors on the participation of households on "equb".

\section{Literature Review}

\subsection{Definition}

Rotating saving and credit association (RoSCAs) is a group of individuals who agree to meet for a defined periods of time to save and borrow together. It is among the oldest and most prevalent saving institution. RoSCAs (Rotating Savings and Credit Associations) are informal, indigenous savings and credit institutions, which are prevalent in both developing and developed economies around the world.

A typical RoSCA works in the following manner. A group of individuals meet together on a regular basis (say once a month or once a week) and contribute some fixed amount of money, decided either mutually or by the leader of the RoSCA, into a 'pot' every time they meet. At the end of each meeting, one member of the group is selected to receive the pot. This can be done either randomly (hence the name - random RoSCA) or by bidding (which results in a bidding RoSCA). This process continues till every member of the group receives the pot of money once. Obviously, those members who have already received the pot earlier cannot receive the pot again, 
though they still have to contribute to the pot. When every member of the group has received the pot of money once, the group is disbanded, or can be started again with different members, different contributions and a possibly different duration between subsequent meetings.

Meetings can be regular or tied to seasonal cash flow cycles in rural communities. Each member contributes the same amount at each meeting, and one member takes the whole sum once. As a result, each member is able to access a larger sum of money during the life of the ROSCA, and use it for whatever purpose she or he wishes. This method of saving is a popular alternative to the risks of saving at home, where family and relatives may demand access to savings.

Every member sees every transaction during the meetings. Since no money has to be retained inside the group, no records have to be kept. These characteristics make the system a model of transparency and simplicity that is well adapted to communities with low levels of literacy and weak systems for protecting collective property rights.

\subsection{Factors affecting the household saving participations on 'equb' \\ 2.1.1 Income Factors}

Members earn an income by working. It is a continuous variable and operationalized as the total earnings of a family from sale of agricultural produce, off-farm and non-farm activities. Income level which shows that when the income level of households increase the saving rate will also increase by some percent.

Anderson and Baland (2002) presented a model of intra-household conflicts in consumption decisions. In their cooperative bargaining framework, men and women, sharing a common budget, exhibit asymmetric preferences for household goods. Those asymmetries drive their model of income which is earned by the household.

According to Abdelkhalek et al. (2009) indicated that income strongly affects the saving level of the household. The expected effect of this variable on rural household saving was positive.

\subsubsection{Expenditure factors}

Expenditure refers to money which is spent by the people for consumption. It is a continuous variable which is measured in Birr. It affects rural households saving negatively. The more the households spends on the consumption, their saving will be reduced.

Rehman et al. (2010) indicated that expenditure significantly and inversely affects household saving. The expected effect of expenditure on rural household saving was negative. People have always a larger preference for the indivisible good and therefore want to save at a higher rate after the expenditure is met. This increases the income of households saving rate.

\subsubsection{Marital status of household head}

Marital Status of household head is also an important factor that has very significant effect on household savings. When household head is un-married, he has no responsibility regarding family. He has less expenditures and more money to save for future needs. But after marriage, he has to look after his family, children, relatives, and have more domestic expenditures than past. Theoretically, household saving is expected to be negatively affected by Marital Status. We have exercised dummy variable to distinguish between un-married and married status.

\subsubsection{Household family size}

This is the size of the household family measured in terms of total number of members in a family which includes the spouse and children. Since food requirements increases with the number of persons in the household, food and non- food expenditure increases with increase in household size and this could reduce the saving of the household. The expected effect of family size on saving is negative.

\subsubsection{Social factors}

According to Wójcik 2007, saving behavior in households are also perceived in the aspect of the society and the community where the people live and interact. Higgins, 1994,"...an internal drive to satisfy an unsatisfied need" motivate the peoples to participate in traditional savings when their relatives or friends participate. People may feel that it is a prestige issue if they do not take part when all the others are a part of it. This implicates about human behavior. First, there are some drives (needs) that make individuals behave in certain ways, and second, individual behavior is goal oriented. Motivation is a continuous process which starts with needs, continues with goal oriented behavior and ends with the satisfaction of needs.

\subsubsection{Economic factors}

It is the percentage of the balance in a deposit account that the savers receive as income from their deposit. It is measured by the sample households earning as interest from their deposit in a year. The interest could encourage or discourage rural households and this could in turn influence their willingness to save in financial institutions. Mahlo (2011) estimated the relationship between household savings and interest rate in South Africa and his result showed that there was a positive relationship but Simleit et al. (2011) found a negative effect on rural household savings. In most cases the interest rate obtained from saving discourages savers and it was expected 
interest rate had negative effect on rural households' savings.

Savings is a mechanism by which economic agents make deliberate choice to allocate a portion of their current income for the purpose of making investment and their increasing their future earning capacity. Theory suggests that household total savings depend on the rate of return on savings, on uncertainty of future incomes, on risk aversion of household, on lifetime or permanent income or wealth, on family characteristics (FAO, 2001).

\subsubsection{Psychological factors}

It is emotion that members feel to receive credit. Some financial institutions like saving and Credit Cooperatives put saving as the primary principle for credit from their institution. Therefore, this principle helps the rural households to improve their saving status. Households with better access to credit have higher tendency to save more than that of households who do not access to credit service. Empirical studies revealed that savings of rural household increases with the amount of credit received, (Desta, 2004). Therefore, the amount of credit received was expected to have positive relationship with household saving.

Saving behavior is fundamental aspect of human survival particularly in rural areas where incomes are unsecured. Long term financial security starts with a regular savings plan for emergencies, unexpected bills, replacement of needed home items and the purchase of special goods and services, such as a boat, a vacation from home or college education. Once a saving component has been established, additional money saved may be used for investments that offer greater potential returns.

\subsection{Conceptual Framework}

Based on review of literature conceptual framework for this study was designed.

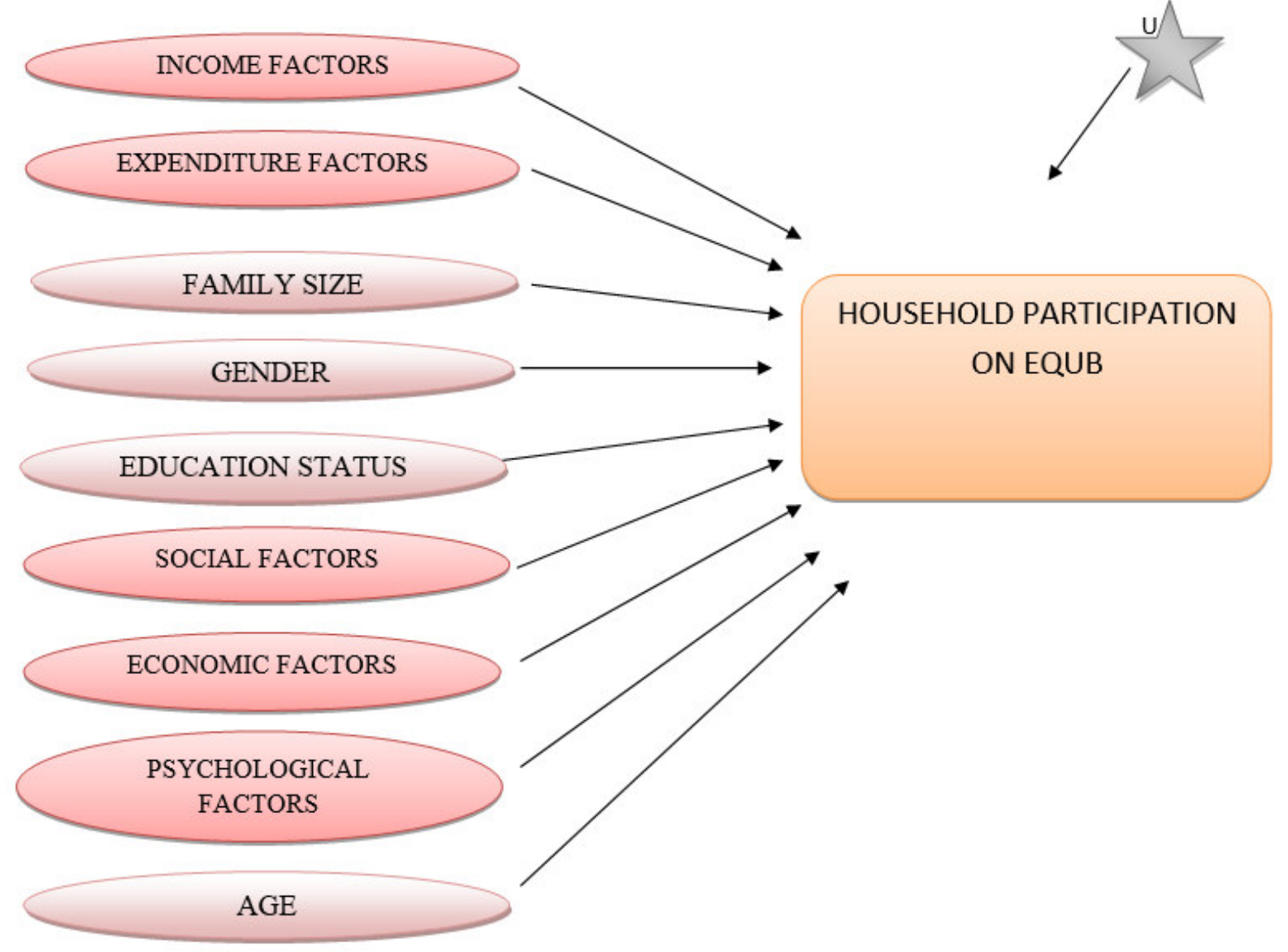

Independent Variables

Dependent Variables

Fig. 2.1.: Compiled by the researchers

\section{Research Methodology}

\subsection{Research Design}

Research design is the conceptual structure within which research is conducted. It constitutes a blue print for the collection, measurement, and analysis of data. This study was based on causal research design which is more preferable to identify the extent and nature of cause-and-effect relationships between the independent variable and dependent variable. 


\subsection{Target Population and sample size determination}

The Target population of the study is the households who are participating in Equb at the three major towns of Wolaita Zone. The target population of the study consists of 61499 households in Wolaita zone of Areka, Boditi and Sodo town. Based on the bases of data obtained from Wolaita zone Finance and Economics office, there are 61499 households at Areka, Boditi and Sodo town. And also large enough to allow for precision, confidence and generalize ability of the research findings. Accordingly, from the total of 61499 households, Sodo town (35302), Areka (14283) and Bodit (11914) the sample size will be determine. The sample size determination for the study will be based on Taro Yemane's a simplified formula to calculate sample sizes'.

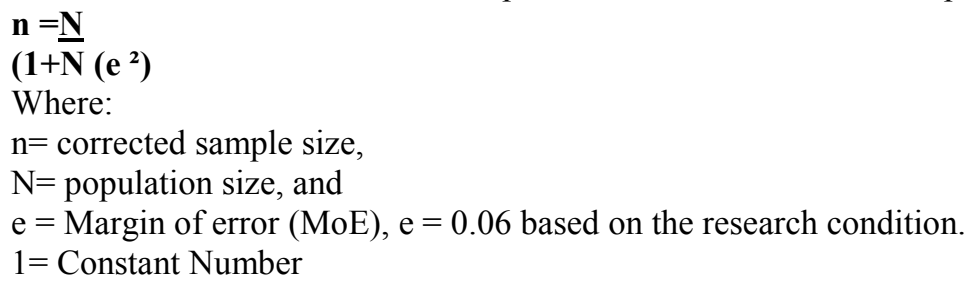

The sample size would be:-

$\mathrm{n}=\underline{61499}$

$\left(1+61499\left(0.06^{2}\right)\right.$

$=277$

Therefore, the sample size of this study will be $\mathbf{2 7 7}$. Sample of $\mathbf{1 4}$ were added to minimize the effect of nonresponse rate and therefore the total sample size were 291.

\section{Data Presentation and Analysis}

A sample size of $\mathbf{2 9 1}$ households were taken from the three towns of Wolaita Zone to collect the necessary information through structured questionnaire within four weeks and $287(\mathbf{9 8 . 6 \% )}$ of household participants were able to return the questionnaire while the rest 4 (1.4\%) responses were not returned. Out of 287 responses 4 questionnaires were filtered out due to incompleteness. Therefore, the study of this research is based on the $\mathbf{2 8 3}$ (97.2\%) household participants' responses data. and the statistical program was used for the analysis and presentation of data in this study was the STATA.

\subsection{Descriptive Statistics for profile of the respondents}

A total of $\mathbf{2 8 3}$ urban households were interviewed for the study. The number of male household respondents are 177 which is $(62.5 \%)$ out of total sample households, while the remaining $\mathbf{1 0 6}$ are female respondents and accounts $(37.5 \%)$ (Table 4.1). Similarly the majority of the surveyed households were comprised of more than three family members.

\begin{tabular}{|c|c|c|c|c|c|}
\hline & & Frequency & Percent & Valid Percent & Cumulative Percent \\
\hline \multirow{3}{*}{ Valid } & Male & 177 & 62.5 & 62.5 & 62.5 \\
\hline & Female & 106 & 37.5 & 37.5 & 100.0 \\
\hline & Total & 283 & 100.0 & 100.0 & \\
\hline
\end{tabular}

Source: Own computation from survey data, 2018 A total of 283 urban households were interviewed for the study. The age of the respondents are categorized as 18-25, 26-35, 36-45, and above 45 years with their respective composition of $10.6 \%, 49.1 \%, 27.6 \%$, and $12.7 \%$, respectively, as shown in Table 4.2

\begin{tabular}{|c|c|c|c|c|}
\hline & Frequency & Percent & Valid Percent & Cumulative Percent \\
\hline $18-25$ & 30 & 10.6 & 10.6 & 10.6 \\
\hline $26-35$ & 139 & 49.1 & 49.1 & 59.7 \\
\hline $36-45$ & 78 & 27.6 & 27.6 & 87.3 \\
\hline Above45 & 36 & 12.7 & 12.7 & 100.0 \\
\hline Total & 283 & 100.0 & 100.0 & \\
\hline
\end{tabular}

Source: Survey data, 2018 STATA output

4.1.2 Descriptive Statistics for Monthly Expenditure Level of the Respondent

According to the survey result majority of the respondents are in the monthly expenditure category of 3001-4000 Ethiopian Birr (36percent) followed by respondents in the income category of 4001-5000Ethiopian Birr (28.6percent) and only 2.8percent the respondents are falling in the monthly expenditure category of 500-1000 Ethiopian birr as shown in Table 4.6. 
Table 4.3 Monthly expenditure level of the respondents

\begin{tabular}{|l|l|r|r|r|r|}
\hline \multicolumn{2}{|l|}{ Table 4.3 Monthly expenditure level of the respondents } \\
\hline $500-1000$ & Frequency & Percent & Valid Percent & Cumulative Percent \\
\hline $1001-2000$ & 8 & 2.8 & 2.8 & 2.8 \\
\hline $2001-3000$ & 20 & 7.1 & 7.1 & 25.9 \\
\hline $3001-4000$ & 43 & 15.2 & 15.2 & 61.1 \\
\hline $4001-5000$ & 102 & 36.0 & 36.0 & 89.8 \\
\hline Above5000 & 81 & 28.6 & 28.6 & 100.0 \\
\hline Total & 29 & 10.2 & 10.2 & 100.0 \\
\hline
\end{tabular}

Source: Survey data, 2018 STATA 11 output

\subsection{Estimation Results}

The survey data contains information on 277 household head respondents of farm households. The model was estimated using STATA. Regressions were run for the household participation on Equb (HPOE) as continuous variable. Table 4.8 on the previous page displayed the definition of all variables used in the multiple linear regression models. As it is evident in the Table 4.8most of the variables included in the model have the expected sign. Moreover, five of the variables found statistically significant at 1 percent level of significance. This indicates that except expenditure factor all other covariates are significantly predicting household participation on Equb.

Table 4.4: Multiple Linear Regression Coefficients

\begin{tabular}{|c|c|c|c|c|c|c|c|}
\hline \multirow[t]{2}{*}{ Model } & \multicolumn{2}{|c|}{$\begin{array}{c}\text { Unstandardized } \\
\text { Coefficients }\end{array}$} & \multirow{2}{*}{$\begin{array}{c}\begin{array}{c}\text { Standardized } \\
\text { Coefficients }\end{array} \\
\text { Beta }\end{array}$} & \multirow[t]{2}{*}{$\mathbf{t}$} & \multirow[t]{2}{*}{ Sig. } & \multicolumn{2}{|c|}{$\begin{array}{c}95.0 \% \text { Confidence } \\
\text { Interval for } \mathbf{B}\end{array}$} \\
\hline & B & $\begin{array}{l}\text { Std. } \\
\text { Error }\end{array}$ & & & & $\begin{array}{l}\text { Lower } \\
\text { Bound }\end{array}$ & $\begin{array}{l}\text { Upper } \\
\text { Bound }\end{array}$ \\
\hline (Constant) & 2.422 & .442 & & 5.478 & .000 & 1.543 & 3.300 \\
\hline SF & .296 & .089 & .368 & 3.338 & $.001 * * *$ & .120 & .472 \\
\hline EcF & .287 & .104 & -.174 & -1.814 & $.002 * * *$ & -.397 & .018 \\
\hline PsF & .312 & .086 & -.093 & -1.043 & $.000 * * *$ & -.262 & .082 \\
\hline
\end{tabular}

*** indicates the variables are strongly significant at 1 level of significance

Source: Survey data, 2018 STATA 11 output

According to survey result, the variables income factor, psychological factor, economic and social factors of households are positively related to household participation on Equb, keeping other factors remain constant, and statistically significant. Hence, we need further interpretation for these variables. While, other things being constant, expenditure factor of households is negatively related with the dependent variable, household participation on Equb, but statistically insignificant. Hence, for these mentioned variables no need of further interpretation.

The significance level indicates whether that variable is statistically significant predictor of the outcome or not. Generally, when the significance level 95\% certain $(p<.05)$ that we are not making an error when we declare something to be significant. As shown in table 4.11 beta $(\beta)$ sign shows the $+v e$ or - ve effect of the independent variables coefficient over the dependent variable. The beta sign of four independent variables shows the positive effect of the predicting dependent variable and one variable shows the negative effect of the predicting dependent variable. The positive sign of the of the four variables means, any increase in the independent variables lead to increase in the dependent variable household participation on Equb and the negative sign of $\beta$ means any increase in the independent variables lead to decrease in the dependent variable household participation on Equb.

According to Table 4.8, the coefficients of the independent variable ( $\beta$ sign) of the all hypotheses proposed by the researcher are acceptable because of it stated a positively relationship with the dependent variable and the rest one hypothesis are negative affect because it shows negative relationship with the dependent variable. But based on the statistical significances of the independent variable over the dependent variable at $1 \%$ level of significance, only four independent variables (IF, SF, EcF and PsF) are significantly contributed for the household participation on Equb at $(\mathrm{P}<0.01)$ level of significance, while $\mathbf{E F}$ is statistically insignificant.

Thus, this implies the IF, SF, EcF and PsF are the most important determinants of household participation on Equb .The variable with the level of significance (sig) value less than 1percent could make a significance contribution to the predicted value of the dependent variable, beyond this level of sig. the variable are not making as s strong significance contribution for the prediction of the dependent variable (Shewamene, 2014; Pallant, 2007; Somekh and Lewinn, 2005). Let us examine a detail interpretation for these covariates which are significantly affecting our dependent variable under subsequent paragraphs. 
Income factor of households has a positive and statistically significant effect on household participation on Equb at 1percent level of significance. With the coefficient of income factor0.324, keeping other factors remain constant as income factor of household increases by one percent, we expect household participation on Equb to increase by 32 percent. This indicates that as income increases as among other factor of income we expect household participation on Equb would increases. This acts as synergy for long run investment of a particular household.

Social factor of household has a positive and statistically significant effect on the household participation on Equb at 1 percent level of significance. With the coefficient of social factor 0.296, being other factors remain constant, as social factor of household increases by one percent, we expect household participation on Equb to increase approximately by 30 percent. Since the variable social factor encompasses marital status of household head, household family size, gender, and educational status of the household head, are implying that these factors are significantly predicting households participation in Equb.

Economic factor of households has a positive and statistically significant effect on household participation on Equb at 1percent level of significance. With the coefficient of economic factor 0.287 , keeping other factors remain constant as economic factor of household increases by one percent, we expect household participation on Equb to increase approximately by 29 percent. This result is consistent with the findings of Kenichi Mizobuch regarding the influences of economic and psychological factors on energy-saving behavior around Matsuyama, Japan, which indicates that economic factors have a positive influence on the decision concerning whether to save electricity or not, which in turn analytically identical to saving money income. Since the variable economic factor encompasses market interest rate and saving mobilization, implying that these factors are significantly predicting household's participation in Equb.

Psychological factor of households has a positive and statistically significant effect on household participation on Equb at 1percent level of significance. With the coefficient of psychological

Factor 0.312, keeping other factors remains constant as economic factor of household increases by one percent, we expect household participation on Equb to increase approximately by 31 percent. According to the study by Ellen K. and Paul W. (2001) in examining the role of personality in household saving found that psychological variables affects the saving behavior of households. In addition, This result is consistent with the findings of Kenichi Mizobuch regarding the influences of economic and psychological factors on energy-saving behavior around Matsuyama, Japan, which indicates that psychological factors have a positive influence on the decision concerning whether to save electricity or not, which in turn analytically identical to saving money income. Since the variable psychological factor encompasses motives to receive credit and saving behavior, implying that these factors are significantly predicting households participation in Equb.

\subsection{Test of Hypothesis}

Using Regression Model as per the table 4.9 hypothesis of the study is tested and the result of the study indicated that all hypotheses proposed by the researcher are acceptable because of it stated a positively relationship with the dependent variable and the rest one hypothesis are negative affect because it shows negative relationship with the dependent variable. But based on the statistical significances of the independent variable over the dependent variable at $1 \%$ level of significance, only four independent variables (IF, SF, EcF and PsF) are significantly contributed for the household participation on Equb at $(\mathrm{P}<0.01)$ level of significance, while $\mathbf{E F}$ is statistically insignificant.

Table 4.5: Summary of Hypothesis Testing Decisions

\begin{tabular}{|l|l|l|l|l|l|}
\hline No & Hypothesis & $\begin{array}{l}\boldsymbol{\beta}- \\
\text { Value }\end{array}$ & P-Value & Sig & $\begin{array}{l}\text { Accept } \\
\text { Reject }\end{array}$ \\
\hline 1 & $\begin{array}{l}\text { H1: income factor has positive and significant } \\
\text { effect on the household participation on Equb }\end{array}$ & 0.324 & $\begin{array}{l}.002< \\
0.01\end{array}$ & significant & $\begin{array}{l}\text { H1 } \\
\text { accepted }\end{array}$ \\
\hline 2 & $\begin{array}{l}\text { H2: expenditure factor of household has a significant } \\
\text { effect on the household participation on Equb. }\end{array}$ & -0.130 & $.161>0.1$ & insignificant & $\begin{array}{l}\text { H2 } \\
\text { rejected }\end{array}$ \\
\hline 3 & $\begin{array}{l}\text { H3: social factor has a positive and significant effect } \\
\text { on the household participation on Equb }\end{array}$ & 0.296 & 0.01 & Significant & $\begin{array}{l}\text { H3 } \\
\text { Accepted }\end{array}$ \\
\hline 4 & $\begin{array}{l}\text { H4: economic factor has a positive and significant } \\
\text { effect on the household participation on Equb }\end{array}$ & 0.287 & $.002<$ & Significant & $\begin{array}{l}\text { H4 } \\
\text { Accepted }\end{array}$ \\
\hline 5 & $\begin{array}{l}\text { H5: psychological factor has a positive and } \\
\text { significant effect on the household participation on } \\
\text { Equb. }\end{array}$ & 0.312 & 0.01 & Significant & $\begin{array}{l}\text { H5 } \\
\text { Accepted }\end{array}$ \\
\hline
\end{tabular}

Source: Survey Result From STATA11 Result 


\section{Conclusion and Recommendations \\ 5.1 Conclusions}

Based on the major findings of the study, the research has the concluded as Broad-based growth, development and economic transformation, via enhancing the saving culture of households in the form of local institutions of social capital like Equb, has been one of the major issues in various development strategies in Ethiopia and yet got little attention by the concerned bodies such as informal financial institutions, government and local community in the Equb process in Ethiopia. Thus, increasing the saving culture of households to mitigate the extent and dimension of poverty and create an internationally competitive agents are among the policy challenges the Ethiopian government is currently meeting. In order to make households as an agent as the engine of economic growth it is important to identify factors influencing household participation in Equb in the context of Ethiopia. This study provides empirical evidence on the factors affecting household participation in Equb by taking 283 sample households from Sodo, Boditi and Areka towns of Wolaita Zone.

\subsection{Recommendations}

The findings of the study call for appropriate supportive interventions to improve the saving culture of households via social capital like participating in Equb in Ethiopia in general and at the study area in particular. According to this study the following recommendations are forwarded:

$>$ The informal sector advocators should establish feasible environment to households to enhance their income level.

$>$ The local government would give due attention to the social factor of household like marital status of household head, household family size, gender, and educational status of the household head.

$>$ The government financial institutions should consider economic factor of households like market interest rate and saving mobilization.

$>$ The local community and the government should consider psychological factor of household's motives to receive credit and saving behavior.

\subsection{Scope of future research}

The factors remained unsolved by the model are large enough to conduct further study in the area. These factors comprise training, financial literacy, timelines of credit, dependency ratio distance, Time value of money to Equb centers and also legal grounds for its establishment. Researches might consider saving behavior as dependent variable and can go for further study on the independent factors for interdependence of variables so that a depth understanding of the variables can be achieved and that it help to clearly identify more factors influence among variables in this study if exist. This was suggested by many authors to deeply investigate the causal research relationship among factors in their levels; it helps to increase the understanding of consequent factors that can bring an impact in the improvement of saving behavior.

\section{REFERENCES}

Abbi M. Kedir \& Gamal Ibrahim, (2011), "ROSCA in urban Ethiopia: are the characteristics of the institution more important than the members", journal of development studies Vol. 47, No. 7, 998-1016.

Ambec, S., \& Treich, N. (2003)..Roscas as financial agreements to cope with social pressure. Centre for Studies in Economics and Finance, Working Paper No. 103. Retrieved on Dec. 20, 2017 from http://www.csef.it/WP/wp103.pdf

Anderson, S. Baland J.-M, and. Moene K. O. (2009). Enforcement in Informal Saving Groups. Journal of Development Economics 90 (1): $14-23$

Anderson, S., Baland, J.M. and Moene, K.O. (2003).Sustainability and organizational design in informal groups, with some evidence from Kenyan Roscas. working paper, University of Oslo

Anderson, Siwan, and Jean-Marie Baland, 'The Economics of Roscas and intra-household Resource Allocation,' Quarterly Journal of Economics (2002), 963-995.

Ardener, S. (1964). The comparative study of rotating credit associations. The Journal of the Royal Anthropological Institute of Great Britain and Ireland 94 (2): 201 - 229.

BalaShanmugam.(1991). Socio-Economic Development through the Informal Credit Market. Modern Asian Studies [online].25(2), Retrieved on Dec. 23, 2017from world wide webhttp://links.jstor.org/sici?sici=0026749X\%28199105\%2925\%3A2\%3C209\%3ASDTTIC\%3E2.0.CO\%3 B2-Fpp217-218

Besley, T., Coate, S., and Loury G. (1994). Rotating Savings and Credit Associations, Credit Markets and Efficiency. Review of Economic Studies, 61 (4): 701-719

Besley, T., Coate, S., and Loury, G. (1993). The Economics of Rotating Savings and Credit Associations. American Economic Review. 83(4): 792-810.

Besley, Timothy and Alec Levenson, 'The Role of Informal Finance in Household Capital Accumulation: 
Evidence from Taiwan,' The Economic Journal, Vol. 106,434, Jan. 1996, 39-59.

Bezabih Emana, Kejela Gemtessa, DhunfaLemessa and GezahegnAyele.(2005)..Informal Finance In Ethiopia: occasional paper No. 13. Addis Ababa. Association of Ethiopian micro finance institution.

Birchall, J., \& Simmons, R. (2004). What motivate members to participate in Co-operative and mutual businesses? A theoretical model and some findings. Annals of Public and Cooperative Economics 75(3): $465-495$.

Bisrat Agegnehu, (2012), "Why do members join indigenous informal financial institution: ROSCA?" an empirical evidence from equbs in Ethiopia, Environmental Economics and Management, Degree thesis No 710 ISSN 1401-4084.

Bouman, F.J. and A.R. Hourtman.1988.Pawn broking as an instrument of rural banking in the third world. Economic development and cultural change, 37(1).

Bouman, F.J.A. 1994. ROSCA and ASCRA: Beyond the financial landscape. In: Bouman, F.J.A. and Hospes, O., Editors, (1994). Financial Landscapes Reconstructed, Westview Press, Boulder, CO, pp. 375-394

Bouman, F.J.A. (1995). Rotating and accumulating savings and credit associations: A development perspective. World Development, 23(30): 371-84.

Coase, R. (1998). The New Institutional Economics. The American Economic Review, 88(2): 72 - 74

Coehn and Koehn .(1980).Ethiopian provincial and municipal government. Michigan state university.

Comhaire .(1966). Wage pool as a form of voluntary association in Ethiopia and other African towns. In: the third international conference of Ethiopian studies. Hailesilassie I university. Institute of Ethiopian studies., PP44-8

Dagnelie, O. \& Lemay-Boucher, P. (2008). Rosca Participation in Benin: a Commitment Issue. UFAE and IAE Working Papers 735.08 .

Dejene Aredo.(2004).The Equb: Towards the quantification of the economic importance of an Ethiopian saving and credit association (RoSCA).Ethiopian Journal of development research, 26(1).

Dejene, A. (1993).The informal and semi-formal financial sectors in Ethiopia: A case study of Equb, Idder, and saving and Credit Cooperatives, African Economic Research Consortium (AERC), Nairobi.

Djankov, S., Lieberman, I., Mukherjee, J., and Nenova, T. (2002).GoingInformal: Benefits and Costs. Draft: The World Bank.

Ellen K. Nyhus and Paul Webley(2001): The role of personality in household saving and borrowing behaviour , Europian journal of personality

Engdawork, D.(1995). Agricultural producer cooperatives: Some lessons of experience from Ethiopia. GeoJournal, 36( 4): 353-360

Federal Democratic Republic of Ethiopia, Ministry of Finance and Economic Development (MOFED). (2002).Ethiopia: Sustainable Development and Poverty Reduction Program. Addis Ababa, Ethiopia

Geertz, C. (1962). The Rotating Credit Association: A "Middle Rung" in Development. Economic Development and Cultural Change 10(3): $241-263$

Gugerty, M. K. (2007). You Can't Save Alone: Commitment in Rotating Savings and Credit Associations in Kenya. Economic Development and Cultural Change 55 (2): 251 -282.

Hammer, J.H. (1976).Prerequisites and limitations on the development of Voluntary self help associations: A case study and comparisons. Anthropological Quarterly, 49(2)

Hansmann, H. (1999). Cooperative Firms in Theory and Practice. Finish Journal of Business Economics, 4, $387-$ 403.

Higgins, J. M. (1994). The management challenge (2nd ed.). New York: Macmillan.

http://etd.aau.edu.et/dspace/bitstream/123456789/1967/1/Temesgen\%20Teshome.pdf

Kedir, A. M., Disney, R. F. \& Dasgupta, I. (2011). Why use RoSCAs when you can use banks? Theory and evidence from Ethiopia. IZA Discussion Paper No. 5767.Retrieved on Dec. 26, 2017 fromhttp://papers.ssrn.com/sol3/papers.cfm?abstract_id=1867036

Kenichi Mizobuchi, The Influences of Economic and Psychological Factors on Energy-Saving Behavior: A Field Experiment in Matsuyama, Japan, Department of Economics, Matsuyama University, 4-2, Bunkyo, Matsuyama

Klonner, Stefan, 'How Roscas Perform as Insurance', mimeo, (2001).

Loayza, N.V. (1997). The Economics of the Informal Sector: A Simple Model and Some Empirical Evidence from Latin America. Washington, D.C. The World Bank 20433.

Mauri, A. (1987).The role of financial intermediation in the mobilization and allocation of household saving in developing countries: interlinks between organized and informal circuits: the case of Ethiopia, International Experts Meeting on Domestic Savings Mobilization, East-West Centre, Honolulu, 2-4 June 1987.Retrieved on Dec. 29, 2017 fromhttp://papers.ssrn.com/sol3/papers.cfm?abstract_id=943426

McKinnon, R.I.(1973). Money and Capital Markets in Economic Development. Washington, DC: The Brookings Institution. 
North, D., (1995), The New Institutional Economics and Development, in J. Hunter, J. Harriss and C. Lewis (eds.), The New Institutional Economics and Third World Development, London: Rout ledge

Rutherford, S.N.D. The Economics of Poverty: How Poor People Manage Their Money. Retrieved on Jan. 04, 2018 fromhttp://media.microfinancelessons.com/resources/Economics_poverty_rutherford.pdf

Rutherford, Stuart (1999), The Poor and Their Money - An Essay about Financial Services for Poor People, Institute of development policy and management, Manchester.

Salole, G.(1986). Equb, Iddir and Meredaja Mahiber as potential development tool in Addis Ababa. In: Symposium on the centenary of Addis Ababa, 24-25November, Addis Ababa. Addis Ababa: Addis Ababa University IES.

Sandsör, A. M. J. (2010). The rotating saving and credit association - An economic, social and cultural institution. MSc. Thesis. University of Oslo. Retrieved on Jan. 05, 2018 fromhttp://www.esop.uio.no/research/masterthesis/sandsor.pdf

Schreiner M. (1999). Formal RoSCAs in Argentina. Development in practice[online].10(2), Retrieved on Jan. 07, 2018 from Worldwide Web http://www.microfinance.com/

Seibel, H.D. (1989). Linking formal and informal financial institutions in Africa and Asia. In: Proceedings of the international conference on Micro enterprises in developing countries. London. IT publications.

Temesgen, T. (2008). Role and potential of Equb in Ethiopia. MSc Thesis, Addis Ababa University. Retrieved on Jan. 09, 2018 from Worldwide Web http://www.microfinance.com/

Tirfe, M. (1999). The paradox of Africa's Poverty: the role of indigenous knowledge, traditional practices and local institutions - the case of Ethiopia. The Red Sea Press, Inc. Asmara, Eritrea

Tokman, V.E. (2001).Integrating the Informal Sector into the Modernization Process. SAIS Review.21 (1), pp.4560.

Umanitoba, University of Manitoba, www.umanitoba.ca, Retrieved on Jan. 20, 2018 from http://www.umanitoba.ca/afs/agric_economics/ardi/history.html

Web http://en.wikipedia.org/wiki/Rotating_Savings_and_Credit_Association/

Wikipedia, the free encyclopedia.(2007). Rotating Savings and Credit Association. Retrieved on Jan. 22, 2018 from World Wide Web http://www.microfinance.com/

Wolfenson, J. D. (2007). 'The Challenges of Globalization: the role of the World Bank. Paper presented at the address to the Bundestag Berlin, Germany. 